\title{
The development of Teacher Academic Emotions (TAE) Scale
}

\author{
Masoud Gramipour1, Mehdi Shariatmadari² and Somayeh Mahdi ${ }^{3}$ \\ ${ }^{1}$ Kharazmi University, Department of Curriculum Development, Iran (ORCID: 0000-0002-3412-3143) \\ ${ }^{2}$ Islamic Azad University, Department of Educational Managament, Iran (ORCID: 0000-0003-2373-8385) \\ ${ }^{3}$ Kharazmi University, Department of Curriculum Development, Iran (ORCID: 0000-0003-3721-3256)
}

\begin{tabular}{|c|c|}
\hline Article Info & Abstract \\
\hline $\begin{array}{l}\text { Article History } \\
\text { Submitted: } 16 \text { August } 2018 \\
\text { Revised: } 23 \text { January } 2019 \\
\text { Published online: 1 April } 2019\end{array}$ & $\begin{array}{l}\text { The purpose of this study was to design a comprehensive and native scale, and } \\
\text { to investigate the validity and reliability of teachers' academic emotions scale } \\
\text { including anxiety, happiness, anger, pride, hope and despair, exhaustion, } \\
\text { shame and guilt through a nine-factors TAE model (second order hierarchy) } \\
\text { and a two-factors TAE model (third-order hierarchy). A sample of } 114 \text { teachers } \\
\text { was obtained from the population through multistage random sampling. } \\
\text { Considering the questionnaire items and sample size, Partial Least Square } \\
\text { Structural Equation Modeling (SEM-PLS) method was used to analyze the data } \\
\text { of the questionnaire. Reliability was measured by three criteria: Cronbach } \\
\text { alpha, composite reliability (CR), and consistency and validity of the } \\
\text { questionnaire by two convergent and divergent validity criteria. Findings } \\
\text { indicate that the reliability and validity of all dimensions were acceptable. } \\
\text { Standardized coefficients and significance coefficients (t values) indicate the } \\
\text { effect of specific structures in that path on each other are significant, and } \\
\text { subsequently, the research hypotheses are confirmed. Furthermore, the } \\
\text { contribution of R2 values in all dimensions was evaluated moderate to high in } \\
\text { measuring all teachers 'emotions. The CVRed and CVCom coefficients indicate } \\
\text { that the quality of the internal model and the external model are higher than } \\
\text { average and according to GOF, the predictive value is generally much higher } \\
\text { than strong, and this TAE model has a prediction power up to } 97 \% \text { of the } \\
\text { covariance based models. Finally, in order to compare two models of second } \\
\text { order and third order hierarchical TAE, the goodness of fit information } \\
\text { measures were evaluated and the second-order hierarchical model was } \\
\text { considered a better model for TAE. }\end{array}$ \\
\hline
\end{tabular}

\section{Introduction}

Emotions are one of the issues which have attracted many practical and theoretical attempts and attention over the past two decades. This attention, to a certain extent, may be due to the role that emotion and emotional regulation play in exterior (individual) behavior. The theorists and scholars have defined emotion in numerous ways, but in sum, it can be defined as a complicated and multi-dimensional phenomenon that leads to readiness for action (Hosseini \& Khayer, 2011). Emotions as social structures as social structure emanates from self-conscious or unconscious judgments about perceived successes in achieving goals or maintaining standards and beliefs during interactions as part of the socio-historical context (Schutz, Cross, Hong \& Osbon, 2007).

\footnotetext{
Address of Corresponding Author

Somayeh Mahdi, PhD, $8^{\text {th }}$ floor, Education and Psychology Faculty, Khanhani St. - Enghelab Ave., Kharazmi University, Tehran / Iran.

$\triangle$ mahdi.somayeh@yahoo.com

How to cite: Gramipour, M., Shariatmadari, M., \& Mahdi, S. (2019). The development of Teacher Academic Emotions (TAE) Scale. Journal of Pedagogical Reserarch, 3(1), 60-79. doi: 10.33902/JPR.2019.5
} 
This definition of emotions suggests that the social matrix intrinsically influences the type and intensity of emotions, as well as how and why one experiences some specific emotions (Hong et al., 2016). The nature of emotions' social structure means that social relations are understood and assessed on basis of individual goals and standards (Denzin, 1984; Lazarus, 1991). As the abovementioned definition emphasizes, the assessment of a person's current status in relation to his goals-whether conscious or unconscious-is necessary for the inference of emotions (Hong et al, 2016).

In this regard, Lazarus (1991) distinguished the process of emotional experience in the form of a primary and secondary assessment. The initial assessment involves communication with the target and proportionate to the goal. Positive emotions are experienced when the individual's condition is measured based on relevance and proportionality. In any case, if the situation is related to the purpose but inconsistent, then negative emotions will be experienced. Secondary assessment is the judgment given by the individual in relation to his/her coping potential to control the state of the experience. Secondary evaluation helps identify and elicit more specific emotions.

The Current views of emotional psychology consider the assessments related to person and position as the crucial determinant of human emotions (Scherer, Schorr, \& Johnstone, 2001). If we look at the issue from the educational and educational point of view, we must admit that these assessments are important because they can be considered as an interface between the factors of the situation and play a positive and effective role in the development of emotions. Some of the dimensions and aspects of assessment that are proposed to describe human emotions are: target matching capacity, expectation and probability, controllability and coping potential, self-causation to be affected by others, and understanding and identifying the emotion-motivating events (Roseman, 2001).

Meanwhile, emotions play a very important role in almost all aspects of learning and learning; therefore, proper understanding and recognition of emotions and feelings in the educational environment and schools are essential (Shutz \& Lanehart, 2002). The interaction between emotions, motivation, and cognition in human life, especially in educational, school and classroom environments, has many complications. However, it does not seem to be enough to address these complexities in research (Gläser-Zikuda, Stuchlikova, \& Janik, 2013).

In giving the ability to human beings, the teacher plays the same role as the kind of nature, so that they can refine and polish the potential and intrinsic capacities of each child and guide them to the plain of ability with the help of slow devotions and appropriate and deserving guidance. The secret key to mastering knowledge with the ability is in teacher's hand. Therefore, only he is the one who gives the abilities in the same way with nature (Raouf, 2004). Since the emotions are relational and involve the interaction between the individual and the environment, the teacher can experience various emotions based on the methods of interaction with each student and the whole dynamics of the classroom in the educational environment (Schutz et al., 2007). The teachers experience different emotions in teaching context; in other words, the teaching is an emotional activity. When the educational goal is realized or the students succeed in doing important assignments, the teacher feels happy: the students are not able to understand the concept, he feels despair, anger against misbehavior, hopelessness frustration against the lack of effort, and The feeling of anxiety is experienced when the teacher's competency is challenged (Hong et al., 2016). Nevertheless, teachers believe that these emotions help them to achieve their goals, hence they often try to regulate emotions (Sutton \& Harper, 2009).

The teacher's emotions are very influential in all his activities in the school, in student and teacher relationships, and in the human relationships of the school; and how these relationships are established, as a kind of teacher-learner interaction, have a direct impact on education. When a teacher feels happy and delightful with coming to the school environment and dealing with students, his work will be more successful and satisfying, he feels less tired, he always strives to enhance his experiences, and his creativity and initiative will be in line with his methods. Then, as a result, he would have more mental health (Shoarinejad, 2015). The teacher, in order to improve 
his performance, should be sensitive to his emotions and feelings. He should be able to accept the students as a group of people who love themselves and have emotions, just like the teacher. He must demonstrate that he really values the students' feelings and that each of them is important to him. Therefore, studying and recognizing the teachers' academic emotions are very significant for students' emotional development, improving the quality of education and achieving the goals and mission of education.

Considering that the assessment of teachers' emotions in Iran's education has been neglected so far, and in only a few studies carried out on the students' academic emotions, this study intends to construct and review the psychometric properties of the local teachers academic emotion (TAE) scale based on global standards of academic emotions assessment, in order to step up the educational system.

\subsection{The academic emotions of teachers}

Pekrun, Gotz, Titz, and Perry (2002) suggested "academic emotions" as a general and universal term for emotions in the educational environment. Academic emotions include emotions and feelings experienced during the teaching and learning process, teaching and educational achievements, and in the classroom (Gläser-Zikuda, Stuchlikova, \& Janik, 2013). Emotions, especially the academic emotions, are always determined by the positive and positive criteria (active versus inactive).

Active positive emotions (happiness, pride, and hope), passive positive emotions (relief and relaxation), negative emotions with high intensity (anxiety, anger, shame, or sin) and negative passive excitement (fatigue, inevitability, and despair) are distinguished (Pekrun, 1992). The assessment of emotions is related to teaching, learning, and success. although it is supposed that active positive emotions have a positive effect and inactive negative ones have a negative impact on teaching and learning, however, simple linear effects between emotions and teaching and learning are not assumed, but nonlinear effects are shaped by the various effects of severe and weak emotions (Sallquist et al., 2009), indirect effects (moderated through precise control) (Dennis, Hong \& Solomon, 2010), and mediation through cognitive processes (Blair, 2002).

In this study, we chose the concept of multi-component emotions to define the teachers' emotions (Sherer, 1984, 2009; Frenzel et al., 2016); i.e. emotions are defined as cognitive, physiological, motivational, and expressive components. In this way, an emotional event is not confined to emotions and feelings (such as anxiety), but with specific thoughts, physiological changes in the body (such as transpiration, secretion of adrenalin hormones, etc.), the tendency to react (such as contrast to avoidance and struggle rather than leaving the state) and the explanatory (declarative) behavior (such as open eyes, fears, etc.) (Frenzel et al., 2016).

Hence, considering the multi-componential nature of emotion, the theoretical framework of the appraisal theory used to describe the feeling and emotions of teachers (Moors, Ellsworth, \& Frijda, 2013). The appraisal theory asserts that it is not an event itself that causes an emotion, but rather the individual's judgment (i.e., appraisal) of the event. The emotion is the result of evaluating information from an environment and from the inside (Lazarus, 1994). Many evaluation dimensions, such as event novelty, fit with purpose, and control capabilities, are proposed, which combine the intensity and quality of the emotional response. This evaluation-based component framework is used to understand and define the causes of emotion. The theoretical basis for constructing tools and external credit hypotheses is the teachers' academic emotions (TAE) scale.

\subsection{The necessity of TAE Scale Development}

Teacher's emotions in schools have been increasingly taken into account in recent years (Frenzel, 2014; Shutz \& Zembylas, 2009; Yin, Huang \& Wang, 2016). So far, research has been done on students' educational emotions and other more general human emotions. But few studies have focused on the teachers' Academic emotions in the classroom, and the lack of integrated approaches in this area dramatically draws attention. The relationship of emotions with the 
teaching of instructors at the school (O'Connor, 2008; Yen, Huang, \& Wang, 2016) and the University (Hagenauer \& Volet, 2014) have been widely acknowledged.

Given the lack of tools for measuring and assessing the teachers' emotions in the educational environment, Frenzel, Pekrun, Guetz (2010) and Frenzel et al (2016) developed the Teacher's Emotion Scale (TES), which included three emotional scales: happiness, anger, and anxiety. Though there are various tools for measuring the various dimensions of teachers 'emotions (e.g., Teacher Emotional Labor Strategy Scale (TELSS) (Yin, 2016) and the Emotion Regulation Ability (ERA) (Brackett, Palomera, Mojsa-Kaja, Reyes, \& Salovey, 2010); Emotional Intelligence Scale (EIS) (Chan, 2006); however, TES is the only scale that measures the discrete emotion that teachers experience while teaching in the classroom.

Frenzel, Guetz, Stephens, and Jacob (2009) chose three scales of happiness, anger, and anxiety based on the importance of these emotions in everyday life, as well as literature and research backgrounds in this area (Frenzel Guetz, Ludke, Pekrun \& Sutton, 2009). Reviews of the qualitative literature on the teaching context, in particular, revealed that joy can be considered the most salient positive emotion that teachers experience in the educational environment. When interactions in the classroom are in the direction of the teacher's goals for teaching, they experience enjoyment (Frenzel et al., 2009; Sutton \& Wheatley, 2003); which Hargreaves (2005) calls the sense of emotional reward.

When the goals do not materialize and teachers appraise that it is caused by students or other people (laziness or misbehavior of the students, parents lack of care, etc.), they experience anger (negative emotion) (Sutton, 2007).

Moreover, they are anxious when they doubt their coping potential to deal with challenging situations or to attain certain classroom goals (Darby, 2008). The pressure to increase the scores of standard tests may lead to anxiety as well (Frenzel, 2014). These three emotions are undoubtedly the most dominant ones, teachers experience during in everyday classroom interactions. However, the researchers believe that teachers experience other types of emotions in education environment (Hong et al., 2016\& Frenzel et al., 2016). Therefore, Hong and colleagues (2016), in addition to the three above-mentioned emotions, added "pride" to the scales of teachers' emotions. The findings of exploratory-confirmatory factor analysis also confirmed the pride index.

Although most scholars in this area believe that there are various emotions in the educational process, so far most researches have focused on the main thrills (anger, happiness, and anxiety). For this reason, Frenzel et al. (2016) suggest that future research should address a wider range of discrete emotions and emotions of teachers in the educational environment, as there are other feelings and emotions that occur less frequently in the classroom, which may have a significant impact on the teaching and learning process. Hence, the measurement and evaluation of other emotions, including feelings of pity toward poor performance of students (Butler, 1994), exhausted (Guetz et al., 2015), pride, despair (Taxer \& Frenzel, 2015) can contribute to the field of teachers' emotions.

Understanding any concept needs to identify its dimensions (Aminabadi, Dehghani \& Khodapanahi, 2011). Due to lack of valid tools for measuring the dimensions of teachers' academic emotions facing in the classroom, it is of great importance to prepare a scale. Our thinking, reasoning, perceiving, learning, and memory are influenced by emotional states. This indicates the need for understanding dynamicity of emotions to perceive human behavior, those who know more about their emotions, are more capable of handling the emotional issues (Gross \& Thompson, 2007). The Emotion is the base of teaching occupation and its nature necessitates teachers to be aware of their academic emotions' dimensions in order to interact properly with students and work efficiently in teaching environments (Newberry, Galant \& Riley, 2013). Identifying and developing academic emotions can improve their performance in the future, and controlling and regulating these emotions can enhance the abilities that help them solve their problems. Confirming this, literature review and research background indicate that feelings and emotions are related to the individual's satisfaction and health. Nevertheless, so far there has not 
been much research in determining the scale of teachers' emotions and the issue of emotion and Teachers' emotions in the classroom, especially in the education system of Iran, are considered as an unexplored topic in the field of educational research.

Therefore, in this paper, in addition to the anxiety, joy, anger indices in the TES (by Frenzel et al., 2010) and the Pride Index of AEQ-T (Academic Emotion Questionnaire-Teachers) (by Hong et al., 2016), we tried to explore other emotions that teachers facing in the classroom, including hope and despair, exhaustion, shame and guilt according to a nine-factor TAE model (second-order hierarchical TAE model) and a two-factor TAE model (third order hierarchical TAE model). It seems that the present study can provide a new horizon in this field by designing a comprehensive and local scale and examining the validity and reliability of the scale, and provide an appropriate context for evaluating the consequences and probable effects of emotions on teachers teaching performance and education system.

In addition, in order to explain the results, concurrent criterion validity, factor validity, and discriminant validity, construct validity and convergence validity of TAE were assessed appropriately.

In this regard, the following research questions are raised:

1. Which TAE model (second or third order hierarchical TAE model) is better validated through SEM-PLS goodness of fit measures?

2. How is the factor structure of TAE scale?

3. How is the construct validity of TAE scale?

4. How is the discriminant validity of TAE scale?

5. How is the convergent validity of TAE scale?

6. How is the criterion (concurrent) validity of TAE scale?

\section{Method}

This research is based on the purpose of the applied type, in terms of data collection, descriptivesurvey method and the type of data collected quantitative (using a questionnaire). To analyze the questionnaires data, SEM-PLS (Structural Equation Modeling Using Partial List Squares) and Smart PLS 2 software was used. The reason for using such method is the ability to analyze complex models with small sample sizes and insensitivity to the normal distribution (Hair, Sarstedt, Ringle \& Gudergan, 2017).

The statistical population of this study includes all secondary school teachers in Tehran during the 2016-2017 academic year. In the pilot phase, 120 teachers were selected as research sample. Using a multi-stage cluster sampling method, 5 districts were selected from the educational districts of Tehran in the north, south, east, west, and center, and from each region, a school was randomly selected. Given the possible drop in samples, 150 questionnaires were distributed and after removing incomplete ones, 114 questionnaires were compiled for data analysis (response rate of $76 \%)$.

To analyze the data collected using PLS software, the validity and reliability of the questionnaire (calculating composite reliability and Cronbach's alpha), factor analysis of the teachers' academic emotions were done, and then the structural model and model fit were examined. Based on the findings, The TAE scale was modified and the final measurement tool was developed.

The construction and implementation method of measurement tool: In this study, a compound form of scale consisting of Frenzel et al TES $(2010,2016)$-including joy, anger and anxiety- and Hong et al AEQ-T (2016) -including pride, joy, anger and anxiety subscales was used to prepare the combined research tools

To prepare Persian version of the scale, back translation method was employed for joy, anger, pride, and anxiety subscales. Therefore, the English version of TES by Frenzel et al (2016) and the revised version (AEQ-T) by Hong et al (2016) was translated to Persian for Iranian teachers. To this end, in order to maintain linguistic and conceptual equivalence, the Persian version was 
retranslated to English (Marsella \& Leong, 1995). Subsequently, two translators discussed the differences between English versions and, through the "repeated review process", these differences were minimized. Based on this, the semantic syntax of the translated version with the original version was carefully examined. Subsequently, based on the literature and background of the research, and also the study of other subscales in the focal group of 6 experts, using semistructured questionnaires, valuable information was obtained from the group's contributions and collaborations, which led to the selection of the subscales: Hope and despair, exhaustion, shame and guilt along with other subscales of pride, joy, anger and anxiety.

In the next step, using the Pekrun scale of emotions (2011) and reviewing previous researches, for selected subscales, some questions were raised. First, a scale of 80 phrases was designed, then, inappropriate phrases were removed, recurrent revisions were done, and some expert in the field of educational psychology and psychometrics applied necessary modifications, the content validity and cultural adaption were confirmed, converted to a 54-phrase questionnaire and prepared for the preliminary implementation.

\section{Results}

73 percent of the sample of the study were female and 25 percent were male; in terms of age, 2 percent of responders were less than 30, 39 percent were 30-40, 39.5 percent were 40-50 and 19 percent were more than 50 years old. Regarding education, 54 percent of participants had B.A and 32 percent had M.A or higher degrees. In terms of work experience, 11 percent had 5-10 years of experience, 31 percent had 10-15 years, 6 percent had 15-20 years, 14 percent had 20-25 years and 32 percent had 25 years and more experience of teaching.

Given that Academic emotions can be examined according to nine-factor and second factor models of emotions including joy, anger, anxiety, pride, hope and disappointment, exhaustion, shame and guilt (second-order hierarchical TAE model) and positive and negative emotions (third order hierarchical TAE model), the information criteria were used to compare these two models. The information criteria are touchstones for evaluating the Goodness of fit. These criteria are based on the concept of entropy and indicate to what extent the use of the statistical model can cause the information loss. In other words, these criteria balance the model's accuracy and complexity (Burnham \& Anderson, 2004). According to the data, in order to compare the second and third order hierarchical models of Academic Emotions in this study, information criteria EN, CAIC, BIC, and AIC were utilized. According to the BIC, CAIC and EN second-order hierarchical TAE model has the lowest value, therefore, is a better-fitted model for teachers' academic emotions (See Table 1).

\section{Table 1.}

IC and BIC information criteria in second-order hierarchy and third order hierarchical models of Academic Emotions

\begin{tabular}{lcc}
\hline & Third order hierarchical model & Second Order hierarchical model \\
\hline AIC & 2091,33 & 2097,49 \\
BIC & 2277.39 & 2250.73 \\
CAIC & 2277,99 & $.2251,21$ \\
EN & 0.88 & 0.83 \\
\hline
\end{tabular}

Since the second order hierarchical TAE model is better than that of the third-order hierarchical TAE model, the results of this model are reported. In order to assess the reliability of TAE questionnaire, the least squares method was used. In this method, reliability is measured by three criteria: 1) Cronbach's alpha, 2) composite reliability (CR), and 3) Communality. Cronbach's alpha coefficient indicates the ability of the items to accurately explain their dimensions. The composite reliability coefficient also determines the correlation of questions of one dimension to one another (Fornell \& Larker, 1981). On the contrary, the Communality is not analyzed on the basis of correlation but it shows the generalizability of each question (from model to model), as claimed by 
Hair, Sarstedt, Pieper, and Ringle (2012). The Cronbach's alpha coefficient for each variable should be above 0.7; also, according to Hair, Black, Babin, and Anderson (2010), CR should be more than 0.7 , but Kline (2010) believes that the models at puberty should be $0.95>C R>0.7$ and the communality for each variable should be above 0.5 . Table 2 illustrates the results of questionnaire's reliability on the basis of three mentioned criteria and the acceptable reliability of the dimensions (See Table 2).

Table 2.

Cronbach's alpha coefficients, Composite Reliability, and Communality of second order hierarchical TAE model

\begin{tabular}{lccc}
\hline & Cronbach's Alpha & Composite Reliability & Communality \\
\hline Enjoyment & 0.91 & 0.93 & 0.73 \\
Anger & 0.78 & 0.86 & 0.60 \\
Anxiety & 0.83 & 0.88 & 0.60 \\
Pride & 0.83 & 0.88 & 0.64 \\
Hope & 0.91 & 0.93 & 0.69 \\
Despair & 0.82 & 0.88 & 0.65 \\
Exhaustion & 0.83 & 0.88 & 0.60 \\
Shame & 0.89 & 0.92 & 0.69 \\
Guilt & 0.88 & 0.91 & 0.73 \\
\hline
\end{tabular}

The Validity of the questionnaire was examined by convergent and divergent validity criteria and through "Partial Least Squares" method. Convergent validity refers to the degree to which two measures of constructs that theoretically should be related, are in fact related (Hulland, 1999). Convergent validity is investigated through Factor Loadings and their significance (see Table 3), AVE criterion (Average Variance Extracted), and the comparison of CR and AVE. Factor loadings are the regression coefficients between the latent and observed variables. As the first prerequisite of convergent validity, Factor loadings should be statistically significant, i.e. their $t$-value after the auto-sampling process is out of this range $[-1.96,1.96]$ and all coefficients of factor loadings should be greater than 0.7 .

For the second prerequisite, Gefen and Straub (2005) recommend the AVE of 0.5 and more, which means that the proposed structure explains about $50 \%$ or more of its markup variances, finally, CR for each variable should be greater than the AVE, if the conditions are met, the convergent validity of the measurement tool is confirmed. According to the table (3) and (4), as well as the comparison of tables (2) and (4), all of the values indicate the convergent validity of the TAE questionnaire. 
Table 3.

Factor Loadings and t-Statistics for Reflective Outer TAE model (Second Order Hierarchical Model)

\begin{tabular}{|c|c|c|c|c|c|c|c|c|}
\hline Items & 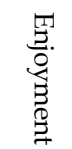 & 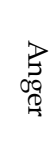 & 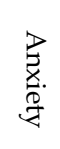 & 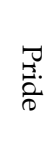 & $\begin{array}{l}\frac{T}{0} \\
\stackrel{0}{0}\end{array}$ & 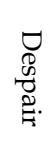 & 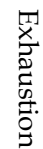 & 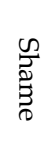 \\
\hline
\end{tabular}

\begin{tabular}{|c|c|c|c|c|c|c|}
\hline \multirow[t]{2}{*}{ AT1 } & $\begin{array}{c}\text { Factor } \\
\text { Loadings }\end{array}$ & 0.78 & & & & \\
\hline & $\mathrm{t}$ & 11.53 & & & & \\
\hline \multirow{2}{*}{ AT2 } & $\begin{array}{c}\text { Factor } \\
\text { Loadings }\end{array}$ & 0.91 & & & & \\
\hline & $\mathrm{t}$ & 25.43 & & & & \\
\hline \multirow[t]{2}{*}{ AT3 } & $\begin{array}{c}\text { Factor } \\
\text { Loadings }\end{array}$ & 0.76 & & & & \\
\hline & $\mathrm{t}$ & 37.21 & & & & \\
\hline \multirow[t]{2}{*}{ AT4 } & $\begin{array}{c}\text { Factor } \\
\text { Loadings }\end{array}$ & 0.92 & & & & \\
\hline & $t$ & 37.21 & & & & \\
\hline \multirow[t]{2}{*}{ AT5 } & $\begin{array}{l}\text { Factor } \\
\text { Loadings }\end{array}$ & 0.91 & & & & \\
\hline & $\mathrm{t}$ & 39.73 & & & & \\
\hline \multirow[t]{2}{*}{ BT2 } & $\begin{array}{c}\text { Factor } \\
\text { Loadings }\end{array}$ & & 0.75 & & & \\
\hline & $t$ & & 7.30 & & & \\
\hline \multirow[t]{2}{*}{ BT3 } & $\begin{array}{l}\text { Factor } \\
\text { Loadings }\end{array}$ & & 0.79 & & & \\
\hline & $t$ & & 18.95 & & & \\
\hline \multirow[t]{2}{*}{ BT4 } & $\begin{array}{c}\text { Factor } \\
\text { Loadings }\end{array}$ & & 0.76 & & & \\
\hline & $t$ & & 6.94 & & & \\
\hline \multirow[t]{2}{*}{ BT5 } & $\begin{array}{l}\text { Factor } \\
\text { Loadings }\end{array}$ & & 0.79 & & & \\
\hline & $\mathrm{t}$ & & 10.71 & & & \\
\hline \multirow[t]{2}{*}{ CT1 } & $\begin{array}{c}\text { Factor } \\
\text { Loadings }\end{array}$ & & & 0.76 & & \\
\hline & $t$ & & & 9.66 & & \\
\hline \multirow[t]{2}{*}{ CT2 } & $\begin{array}{c}\text { Factor } \\
\text { Loadings }\end{array}$ & & & 0.78 & & \\
\hline & $t$ & & & 18.84 & & \\
\hline \multirow[t]{2}{*}{ СТ3 } & $\begin{array}{c}\text { Factor } \\
\text { Loadings }\end{array}$ & & & 0.80 & & \\
\hline & $t$ & & & 13.88 & & \\
\hline \multirow[t]{2}{*}{ CT4 } & $\begin{array}{l}\text { Factor } \\
\text { Loadings }\end{array}$ & & & 0.81 & & \\
\hline & $\mathrm{t}$ & & & 17.91 & & \\
\hline \multirow[t]{2}{*}{ CT5 } & $\begin{array}{c}\text { Factor } \\
\text { Loadings }\end{array}$ & & & 0.73 & & \\
\hline & $t$ & & & 9.90 & & \\
\hline \multirow[t]{2}{*}{ DT2 } & $\begin{array}{l}\text { Factor } \\
\text { Loadings }\end{array}$ & & & & 0.67 & \\
\hline & $t$ & & & & 7.58 & \\
\hline \multirow[t]{2}{*}{ DT3 } & $\begin{array}{c}\text { Factor } \\
\text { Loadings }\end{array}$ & & & & 0.78 & \\
\hline & $t$ & & & & 9.33 & \\
\hline \multirow[t]{2}{*}{ DT5 } & $\begin{array}{c}\text { Factor } \\
\text { Loadings }\end{array}$ & & & & 0.88 & \\
\hline & $\mathrm{t}$ & & & & 33.61 & \\
\hline \multirow[t]{2}{*}{ DT6 } & $\begin{array}{l}\text { Factor } \\
\text { Loadings }\end{array}$ & & & & 0.86 & \\
\hline & $t$ & & & & 32.33 & \\
\hline \multirow[t]{2}{*}{ ET1 } & $\begin{array}{l}\text { Factor } \\
\text { Loadings }\end{array}$ & & & & & 0.85 \\
\hline & $t$ & & & & & 27.39 \\
\hline \multirow{2}{*}{ ET2 } & $\begin{array}{l}\text { Factor } \\
\text { Loadings }\end{array}$ & & & & & 0.83 \\
\hline & $t$ & & & & & 23.84 \\
\hline ET3 & $\begin{array}{c}\text { Factor } \\
\text { Loadings }\end{array}$ & & & & & 0.81 \\
\hline
\end{tabular}




\section{Table 3 continued}

\begin{tabular}{|c|c|c|c|c|c|c|}
\hline & $\mathrm{t}$ & 15.16 & & & & \\
\hline \multirow[t]{2}{*}{ ET4 } & $\begin{array}{l}\text { Factor } \\
\text { Loadings }\end{array}$ & 0.83 & & & & \\
\hline & $\mathrm{t}$ & 19.28 & & & & \\
\hline \multirow[t]{2}{*}{ ET5 } & $\begin{array}{l}\text { Factor } \\
\text { Loadings }\end{array}$ & 0.87 & & & & \\
\hline & $\mathrm{t}$ & 32.88 & & & & \\
\hline \multirow[t]{2}{*}{ ET6 } & $\begin{array}{l}\text { Factor } \\
\text { Loadings }\end{array}$ & 0.79 & & & & \\
\hline & $\mathrm{t}$ & 16.09 & & & & \\
\hline \multirow[t]{2}{*}{ FT2 } & $\begin{array}{c}\text { Factor } \\
\text { Loadings }\end{array}$ & & 0.81 & & & \\
\hline & $\mathrm{t}$ & & 15.93 & & & \\
\hline \multirow[t]{2}{*}{ FT3 } & $\begin{array}{l}\text { Factor } \\
\text { Loadings }\end{array}$ & & 0.74 & & & \\
\hline & $\mathrm{t}$ & & 10.97 & & & \\
\hline \multirow[t]{2}{*}{ FT5 } & $\begin{array}{l}\text { Factor } \\
\text { Loadings }\end{array}$ & & 0.794 & & & \\
\hline & $\mathrm{t}$ & & 12.71 & & & \\
\hline \multirow[t]{2}{*}{ FT6 } & $\begin{array}{c}\text { Factor } \\
\text { Loadings }\end{array}$ & & 0.87 & & & \\
\hline & $\mathrm{t}$ & & 22.18 & & & \\
\hline \multirow[t]{2}{*}{ GT1 } & $\begin{array}{c}\text { Factor } \\
\text { Loadings }\end{array}$ & & & 0.83 & & \\
\hline & $\mathrm{t}$ & & & 16.57 & & \\
\hline \multirow[t]{2}{*}{ GT2 } & $\begin{array}{l}\text { Factor } \\
\text { Loadings }\end{array}$ & & & 0.85 & & \\
\hline & $\mathrm{t}$ & & & 19.49 & & \\
\hline \multirow[t]{2}{*}{ GT3 } & $\begin{array}{l}\text { Factor } \\
\text { Loadings }\end{array}$ & & & 0.75 & & \\
\hline & $\mathrm{t}$ & & & 10.51 & & \\
\hline \multirow[t]{2}{*}{ GT5 } & $\begin{array}{c}\text { Factor } \\
\text { Loadings }\end{array}$ & & & 0.72 & & \\
\hline & $\mathrm{t}$ & & & 11.61 & & \\
\hline \multirow[t]{2}{*}{ GT6 } & $\begin{array}{c}\text { Factor } \\
\text { Loadings }\end{array}$ & & & 0.71 & & \\
\hline & $\mathrm{t}$ & & & 10.24 & & \\
\hline \multirow[t]{2}{*}{ HT2 } & $\begin{array}{l}\text { Factor } \\
\text { Loadings }\end{array}$ & & & & 0.86 & \\
\hline & $\mathrm{t}$ & & & & 22.72 & \\
\hline \multirow[t]{2}{*}{ HT3 } & $\begin{array}{c}\text { Factor } \\
\text { Loadings }\end{array}$ & & & & 0.87 & \\
\hline & $\mathrm{t}$ & & & & 21.78 & \\
\hline \multirow[t]{2}{*}{ HT4 } & $\begin{array}{c}\text { Factor } \\
\text { Loadings }\end{array}$ & & & & 0.85 & \\
\hline & $\mathrm{t}$ & & & & 22.78 & \\
\hline \multirow[t]{2}{*}{ HT5 } & $\begin{array}{l}\text { Factor } \\
\text { Loadings }\end{array}$ & & & & 0.84 & \\
\hline & $\mathrm{t}$ & & & & 20.58 & \\
\hline \multirow[t]{2}{*}{ HT6 } & $\begin{array}{l}\text { Factor } \\
\text { Loadings }\end{array}$ & & & & 0.75 & \\
\hline & $\mathrm{t}$ & & & & 10.46 & \\
\hline \multirow[t]{2}{*}{ IT2 } & $\begin{array}{l}\text { Factor } \\
\text { Loadings }\end{array}$ & & & & & 0.89 \\
\hline & $t$ & & & & & 6.68 \\
\hline \multirow[t]{2}{*}{ IT3 } & $\begin{array}{l}\text { Factor } \\
\text { Loadings }\end{array}$ & & & & & 0.87 \\
\hline & $\mathrm{t}$ & & & & & 5.34 \\
\hline \multirow[t]{2}{*}{ IT4 } & $\begin{array}{l}\text { Factor } \\
\text { Loadings }\end{array}$ & & & & & 0.768 \\
\hline & $\mathrm{t}$ & & & & & 4.95 \\
\hline IT6 & $\begin{array}{c}\text { Factor } \\
\text { Loadings }\end{array}$ & & & & & 0.88 \\
\hline $\begin{array}{l}\text { Enjoy } \\
\text { DT6) }\end{array}$ & $\begin{array}{c}\mathrm{t} \\
\text { ent (Questio } \\
\text { lope (Questi }\end{array}$ & $\begin{array}{l}\text { ty (Que } \\
\text { 6); Exha } \\
\text { IT2-IT3 }\end{array}$ & $\begin{array}{l}\text { is CT1 to } \\
\text { n (GT1- } \\
\text {-IT6) }\end{array}$ & $\begin{array}{l}\text { 5); Pride } \\
\text {-GT3-GT }\end{array}$ & $\begin{array}{l}\text { estions } \\
\text { T6); Sha }\end{array}$ & $\begin{array}{c}15.28 \\
\text { T3-DT5- } \\
\text { uestions }\end{array}$ \\
\hline
\end{tabular}


Table 4.

The AVE for Reflective Outer TAE model (Second Order Hierarchical Model)

\begin{tabular}{ll}
\hline & AVE \\
\hline Enjoyment & 0.735 \\
\hline Anger & 0.605 \\
\hline Anxiety & 0.603 \\
\hline Pride & 0.645 \\
\hline Hope & 0.689 \\
\hline Despair & 0.647 \\
\hline Exhaustion & 0.601 \\
\hline Shame & 0.699 \\
\hline Guilt & 0.729 \\
\hline
\end{tabular}

Fornel and Larker (1981) proposed a comparison of the AVE square root of each structure with the values of the correlation coefficients between structures to examine the divergent validity. As shown in the following matrix (See Table 5), the values of matrix main diagonal (the square root of the AVE coefficients of each structure) are greater than the values of the correlation coefficients between each construct with other structures, which indicates the acceptable divergent validity of the TAE scale.

Table 5.

The Comparative Matrix of AVE Square Root and Correlation Coefficients (The Divergent Validity of Second Order Hierarchical TAE model)

\begin{tabular}{cccccccccc}
\hline & Enjoyment & Anger & Anxiety & Pride & Hope & Despair & Exhaustion & Shame & Guilt \\
\hline Enjoyment & 0.857 & & & & & & & & \\
\hline Anger & 0.311 & 0.778 & & & & & & & \\
\hline Anxiety & 0.331 & 0.606 & 0.777 & & & & & & \\
\hline Pride & 0.391 & 0.265 & 0.290 & 0.803 & & & & & \\
\hline Hope & 0.586 & 0.342 & 0.403 & 0.712 & 0.830 & & & & \\
\hline Despair & 0.298 & 0.574 & 0.638 & 0.440 & 0.517 & 0.804 & & & \\
\hline Exhaustion & 0.471 & 0.561 & 0.483 & 0.441 & 0.545 & 0.669 & 0.775 & & \\
\hline Shame & 0.072 & 0.208 & 0.421 & 0.183 & 0.262 & 0.439 & 0.363 & 0.836 & \\
\hline Guilt & -0.003 & 0.080 & 0.274 & 0.002 & 0.102 & 0.110 & 0.121 & 0.665 & 0.854 \\
\hline
\end{tabular}

Moreover, cross-loadings were used to assess the divergent validity, it indicates that items would not load on multiple factors (Hensler, Ringel \& Sinkovics, 2009). The cross-loadings of variables are greater than 0.7 , and this fact reflects that the reflective outer TAE model has divergent validity (See Table 6).

Given four tests of convergent and two tests of divergent validity, the TAE model has got the construct validity. The variance-based structural equation modeling methods such as PLS offer quality model indices instead of chi-square-based fit indices. These indices show whether the research data in the form of a measuring or structural model correctly reflect the sample and predict the population. PLS is essentially based on the prediction of behaviors of the population. But the question is whether this prediction is powerful. This question is responded by quality indices. 
Table 6.

The Cross Loadings of Variables in Reflective Outer TAE model (Second-Order Hierarchical Model)

\begin{tabular}{|c|c|c|c|c|c|c|c|c|c|}
\hline & Enjoyment & Anger & Anxiety & Pride & Hope & Despair & Exhaustion & Shame & Guilt \\
\hline AT1 & 0.781 & 0.214 & 0.124 & 0.310306 & 0.440 & 0.094 & 0.307 & -0.006 & -0.098 \\
\hline AT2 & 0.907 & 0.244 & 0.281 & 0.321858 & 0.514 & 0.292 & 0.421 & 0.076 & -0.057 \\
\hline AT3 & 0.757 & 0.198 & 0.274 & 0.325794 & 0.452 & 0.256 & 0.366 & 0.078 & 0.043 \\
\hline AT4 & 0.917 & 0.298 & 0.323 & 0.353295 & 0.570 & 0.310 & 0.435 & 0.127 & 0.089 \\
\hline AT5 & 0.910 & 0.356 & 0.370 & 0.364092 & 0.521 & 0.282 & 0.464 & 0.018 & -0.018 \\
\hline BT2 & 0.191 & 0.754 & 0.316 & 0.293388 & 0.282 & 0.413 & 0.393 & 0.128985 & 0.076737 \\
\hline BT3 & 0.309 & 0.795 & 0.427 & 0.256 & 0.303 & 0.458 & 0.511 & 0.144 & 0.062 \\
\hline BT4 & 0.304 & 0.761 & 0.476 & 0.110 & 0.261 & 0.432 & 0.416 & 0.149 & -0.009 \\
\hline BT5 & 0.162 & 0.799 & 0.652 & 0.168 & 0.220 & 0.479 & 0.417 & 0.221 & 0.117 \\
\hline CT1 & 0.148 & 0.630 & 0.755 & 0.211 & 0.164 & 0.546 & 0.398 & 0.317 & 0.133 \\
\hline CT2 & 0.196 & 0.499 & 0.778 & 0.258 & 0.270 & 0.493 & 0.362 & 0.331 & 0.178 \\
\hline CT3 & 0.274 & 0.319 & 0.804 & 0.184 & 0.284 & 0.374 & 0.264 & 0.335 & 0.337 \\
\hline CT4 & 0.369 & 0.436 & 0.809 & 0.213 & 0.424 & 0.513 & 0.412 & 0.322 & 0.233 \\
\hline CT5 & 0.277 & 0.468 & 0.732 & 0.255 & 0.393 & 0.539 & 0.423 & 0.331 & 0.186 \\
\hline DT2 & 0.170 & 0.127 & 0.053 & 0.670 & 0.243 & 0.161 & 0.187 & -0.032 & -0.181 \\
\hline DT3 & 0.241 & 0.118 & 0.166 & 0.781 & 0.379 & 0.209 & 0.229 & 0.067 & -0.063 \\
\hline DT5 & 0.370 & 0.253 & 0.335 & 0.880 & 0.719 & 0.519 & 0.431 & 0.229 & 0.062 \\
\hline DT6 & 0.385 & 0.282 & 0.257 & 0.865 & 0.714 & 0.372 & 0.446 & 0.193 & 0.049 \\
\hline ET1 & 0.608 & 0.332 & 0.358 & 0.657 & 0.847 & 0.441 & 0.471 & 0.154 & 0.025 \\
\hline ET2 & 0.569 & 0.407 & 0.354 & 0.573 & 0.829 & 0.517 & 0.552 & 0.227 & 0.089 \\
\hline ET3 & 0.496 & 0.252 & 0.302 & 0.502 & 0.814 & 0.384 & 0.413 & 0.175 & 0.092 \\
\hline ET4 & 0.392 & 0.223 & 0.391106 & 0.591 & 0.832 & 0.436 & 0.421 & 0.238 & 0.078 \\
\hline ET5 & 0.476 & 0.313 & 0.354087 & 0.660 & 0.866 & 0.477 & 0.498 & 0.275 & 0.146 \\
\hline ET6 & 0.342 & 0.129 & 0.223819 & 0.548 & 0.789 & 0.276 & 0.323 & 0.238 & 0.076 \\
\hline FT2 & 0.382 & 0.440 & 0.515240 & 0.394 & 0.481 & 0.811 & 0.554 & 0.308 & 0.0268 \\
\hline FT3 & 0.149 & 0.494 & 0.462 & 0.241 & 0.361 & 0.736 & 0.401524 & 0.286 & 0.092 \\
\hline FT5 & 0.109 & 0.413 & 0.465 & 0.399 & 0.351 & 0.794 & 0.522 & 0.355 & 0.181 \\
\hline FT6 & 0.284 & 0.505 & 0.598 & 0.368 & 0.453 & 0.870 & 0.646 & 0.450 & 0.067 \\
\hline GT1 & 0.208 & 0.633 & 0.454 & 0.294 & 0.330 & 0.641 & 0.834 & 0.317 & 0.053 \\
\hline GT2 & 0.363 & 0.497 & 0.458 & 0.305 & 0.492 & 0.635 & 0.846 & 0.373 & 0.158 \\
\hline GT3 & 0.317 & 0.402 & 0.321 & 0.305 & 0.393 & 0.476 & 0.753 & 0.238 & 0.089 \\
\hline GT5 & 0.545 & 0.339 & 0.3197 & 0.385 & 0.475 & 0.381 & 0.718 & 0.163 & 0.066 \\
\hline GT6 & 0.412 & 0.274 & 0.298 & 0.437 & 0.421 & 0.428 & 0.715 & 0.296 & 0.092 \\
\hline HT2 & 0.027 & 0.166 & 0.331 & 0.140 & 0.173 & 0.359 & 0.262 & 0.864 & 0.467 \\
\hline HT3 & 0.009 & 0.149 & 0.301 & 0.149 & 0.162 & 0.328 & 0.243 & 0.867 & 0.470 \\
\hline HT4 & 0.098 & 0.191 & 0.356 & 0.105 & 0.203 & 0.405 & 0.351 & 0.852 & 0.637 \\
\hline HT5 & 0.090 & 0.166 & 0.378 & 0.159 & 0.199 & 0.274 & 0.256 & 0.843 & 0.704 \\
\hline HT6 & 0.067 & 0.189 & 0.379 & 0.206 & 0.335 & 0.448 & 0.380 & 0.750 & 0.480 \\
\hline IT2 & -0.055 & 0.069 & 0.287 & -0.021 & 0.0385 & 0.111 & 0.123 & 0.639 & 0.890 \\
\hline IT3 & -0.098 & 0.012 & 0.172 & -0.061 & 0.0219 & 0.063 & 0.055 & 0.544 & 0.868 \\
\hline IT4 & -0.049 & -0.002 & 0.158 & -0.058 & 0.044 & -0.001 & 0.019 & 0.398 & 0.768 \\
\hline IT6 & 0.111 & 0.131 & 0.266 & 0.079 & 0.182 & 0.138 & 0.152 & 0.613 & 0.882 \\
\hline
\end{tabular}

Enjoyment (Questions AT1 to AT5), Anger (Questions BT2 to BT5); Anxiety (Questions CT1 to CT5); Pride (Questions DT2-DT3-DT5-DT6); Hope (Questions ET1 to ET6); Despair (Questions FT2-FT3-FT5-FT6); Exhaustion (GT1-GT2-GT3-GT5-GT6); Shame (Questions HT2 to HT6); Guilt (Questions IT2-IT3-IT4-IT6) 
Table 7.

The quality test of reflective outer TAE model CVCom

\begin{tabular}{ll}
\hline & $\mathbf{1 - S S E} /$ SSO \\
\hline Enjoyment & 0.715 \\
\hline Anger & 0.547 \\
\hline Pride & 0.558 \\
\hline Hope & 0.622 \\
\hline Despair & 0.676 \\
\hline Exhaustion & 0.602 \\
\hline Shame & 0.597 \\
\hline Guilt & 0.698 \\
\hline
\end{tabular}

For this purpose, the Cross Validity Communality (CVCom) is used. This method was first presented by Chen (1998) and was repeated in the articles of Hensler et al. (2009) and Hair et al (2010). For each variable, CVCom is compared with the following values:
0.02
0.15
0.35
Weak
Average
Strong

As shown in Table 7, all CVCom coefficients are greater than 0.35 , so the quality of the measurement model (outer TAE model) is very strong (See Table 7).

After analyzing the reliability and validity, in this section, the cause-effect relation between the teachers' academic emotion and its dimensions was examined by PLS Smart 2 software. The output obtained from the implementation of the TAE model containing standardized coefficients and the significance coefficients ( $t$ values) is given in Table (3). When the $t$ value of a path is in an interval greater than +1.96 , it indicates the significance of the effect of the specific construct in that path on one another, and as a result, the research main hypotheses are confirmed (Vinzi, Trinchera \& Amato, 2010). According to table 8 , the coefficient of $t$ between the latent variables and the main construct of the research is more than 1.96, i.e. research hypotheses are confirmed.

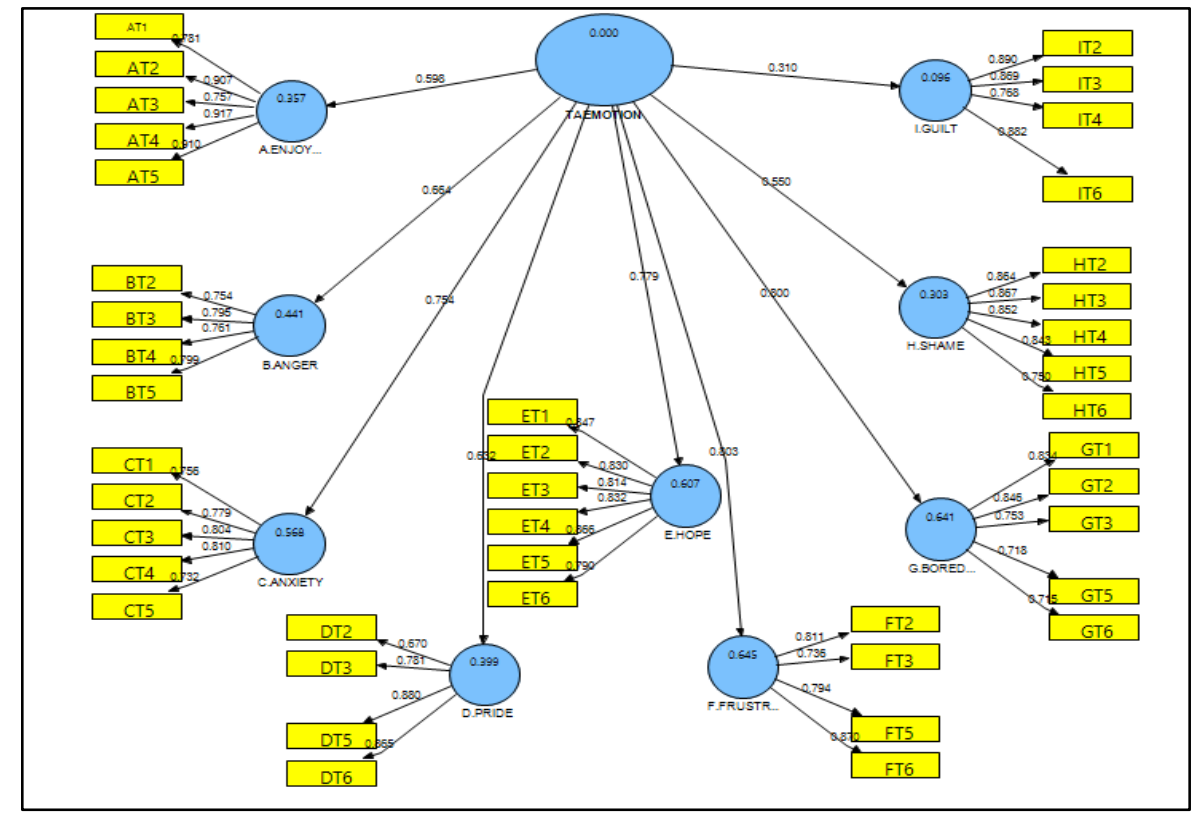

Figure 1. The Outer TAE model for Estimating Standardized Coefficients 


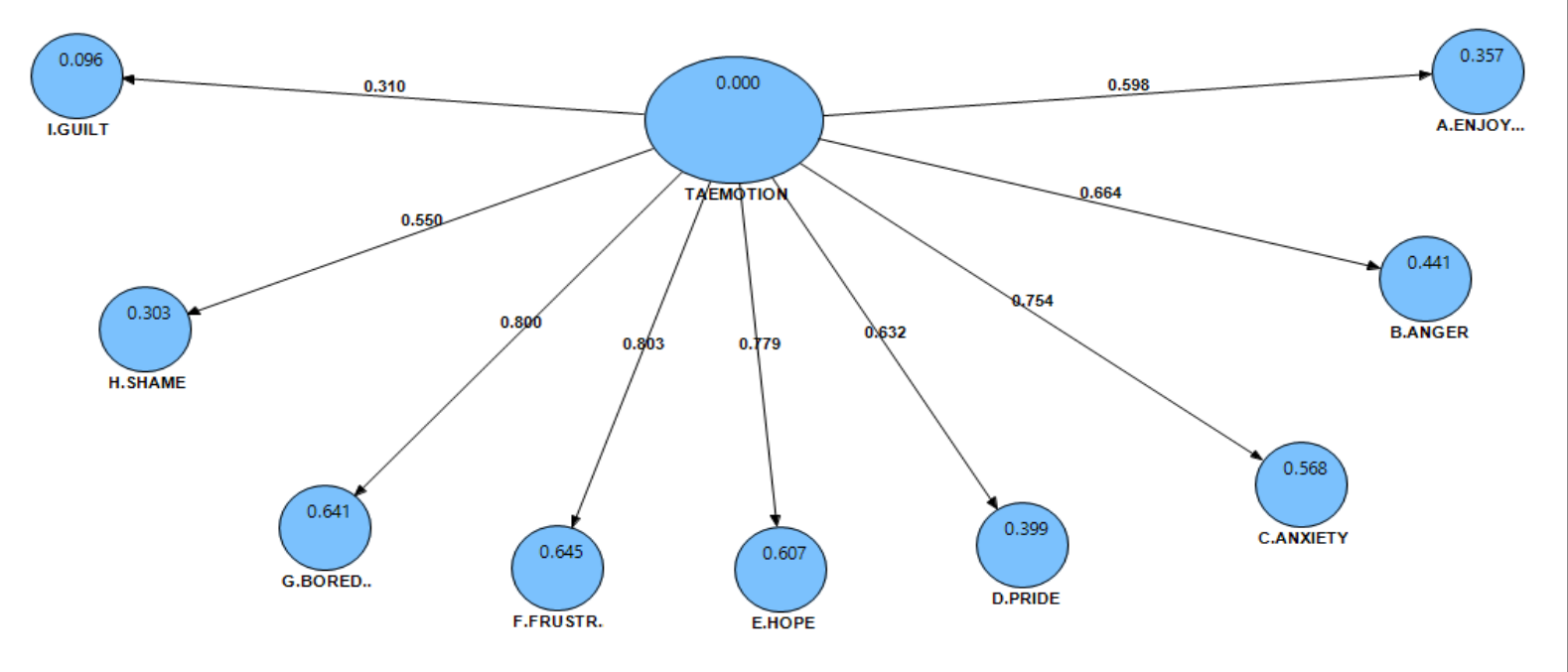

Figure 2. The Inner TAE model for Estimating Standardized Coefficients

Table 8.

Path coefficients and the significance of path coefficients

\begin{tabular}{cccc}
\hline Hypotheses & $\boldsymbol{\beta}$ Path Coefficient & t Value & Result \\
\hline $\mathrm{H}_{1}$ & 0.598 & 6.171 & Confirmed \\
\hline $\mathrm{H}_{2}$ & 0.664 & 13.496 & Confirmed \\
\hline $\mathrm{H}_{3}$ & 0.754 & 11.252 & Confirmed \\
\hline $\mathrm{H}_{4}$ & 0.632 & 11.603 & Confirmed \\
\hline $\mathrm{H}_{5}$ & 0.779 & 16.828 & Confirmed \\
\hline $\mathrm{H}_{6}$ & 0.803 & 11.887 & Confirmed \\
\hline $\mathrm{H}_{7}$ & 0.800 & 16.524 & Confirmed \\
\hline $\mathrm{H}_{8}$ & 0.550 & 4.426 & Confirmed \\
\hline $\mathrm{H}_{9}$ & 0.310 & 3.210 & Confirmed \\
\hline
\end{tabular}

Also, the values of $\mathrm{R}^{2}$, the extent that a particular endogenous construct explains variance and predictive accuracy, indicates that the contribution of all dimensions in measuring latent variable is moderate to high.

Table 9.

Determination Coefficients $\left(R^{2}\right)$ for TAE model

\begin{tabular}{lc}
\hline & R Square \\
\hline Enjoyment & 0.357 \\
\hline Anger & 0.441 \\
\hline Anxiety & 0.568 \\
\hline Pride & 0.399 \\
\hline Hope & 0.607 \\
\hline Despair & 0.645 \\
\hline Exhaustion & 0.641 \\
\hline Shame & 0.303 \\
\hline Guilt & 0.096 \\
\hline
\end{tabular}

Then the "predicting quality" of inner TAE model was evaluated for a larger sample of the same population. For the $\mathrm{Q}^{2}$ test, we need to compare the value of CVRed with the three values of Hensler et al. (2009), the results of Table 10 show that the quality of the inner TAE model around the research endogenous variables is higher than the average. 
Table 10.

Inner TAE model Quality $\left(Q^{2}\right)$

\begin{tabular}{lc}
\hline & CVRed \\
Enjoyment & 1-SSE/SSO \\
\hline Anger & 0.256 \\
\hline Anxiety & 0.258 \\
\hline Pride & 0.332 \\
\hline Hope & 0.226 \\
\hline Despair & 0.408 \\
\hline Exhaustion & 0.414 \\
\hline Shame & 0.384 \\
\hline Guilt & 0.205 \\
\hline
\end{tabular}

On the one hand, the CVCom, which measures the quality of the outer TAE model, is very strong, i. e. the outer TAE model has a high quality, on the other hand, the CVRed index shows that the inner TAE model has a high moderate quality. For the final conclusion on the quality of the TAE model, the GOF index, presented by Tenenhaus, Amato and Winsey (2004) and Tenenhaus, Winsey, Chatelin \& Lauro (2005), was used, that combines the quality of two mentioned models and analyzes the general model of PLS.

$$
\begin{gathered}
\text { GoF }=\sqrt{\overline{\text { communality }} \times \overline{R^{2}} .} \\
\text { GOF }=0.546
\end{gathered}
$$

Given the value of GOF, our prediction quality is generally much higher than strong and based on Hair, Sarstedt, Ringle, and Gudergan (2017), the TAE model has the power of prediction up to $97 \%$ of covariance-based SEM. Moreover, the questionnaire of "positive/negative affect" scale (PANAS) (by Watson, Clark \& Neglen, 1999) and "teacher's sense of efficacy" -short form- scale (TSES) (by Woolfolk Hoy) was administered to determine the criterion validity of the present questionnaire. For the scores obtained from these two tests, the correlation coefficient was calculated. As shown in Table 11, all correlation coefficients are significant at the level of 0.05.

Table 11.

The Correlation Coefficients of TAE, PANAS \& TSES

\begin{tabular}{ccccc}
\hline & & \multicolumn{2}{c}{ PANAS } & TSES \\
\hline \multirow{2}{*}{ TAE } & Positive Emotions & $0.41^{*}$ & $-0.33^{*}$ & $0.37^{*}$ \\
\cline { 2 - 5 } & Negative Emotions & $-0.38^{*}$ & $0.39^{*}$ & $-0.27^{*}$ \\
\hline${ }^{*} \mathbf{0 . 0 5}{ }^{* * \mathbf{0 . 0 1}}$ & & & & \\
\hline
\end{tabular}

\section{Discussion and Conclusion}

The purpose of this study is to construct and review the psychometric properties of TAE questionnaire. To this end, in addition to the anxiety, happiness, and anger indices of the TES (Frenzel et al., 2010) and the Pride Index of AEQ-T (Hong et al., 2016), for the first time in the field of teachers' academic emotions research, other emotions, including hope and despair, exhaustion, shame and guilt indices, were examined in a nine-factor TAE model (second-order hierarchy) and a two-factor TAE model (third-order hierarchy). The reliability was measured by three criteria: 1 ) Cronbach alpha, 2) composite reliability (CR), and 3) Communality. The results show that the reliability of the dimensions is accepted. The validity of the TAE questionnaire was assessed by 
convergent and divergent validity criteria and using partial least squares method. Findings of the research show that all coefficients of factor loadings are greater than 0.7, the AVE is greater than 0.5 and the CR for each variable is greater than the AVE, therefore, the convergent validity of the TAE scale is confirmed. To investigate the divergent validity, the AVE root of each construct was compared with the values of the correlation coefficients between the constructs. The results indicate that values of the square root of AVE coefficients are greater than that of correlation coefficients between each construct with others. This shows that the divergent validity of TAE construct is accepted. Moreover, to examine the divergent validity, cross-loadings were used, cross loads of variables are more than 0.7 and the reflective outer TAE model has divergent validity. All coefficients of CVCom are greater than 0.35 , so the quality of the measurement model (outer TAE model) is very strong. After examining the reliability and validity in the section, the cause-effect relation between the teachers' academic emotions and its dimensions was examined. The output obtained, containing standardized coefficients and significance coefficients ( $t$ values), indicates the significance of the effect of the specific construct in that path on one another, and as a result, the research main hypotheses are confirmed. The values of R2 indicates that the contribution of all dimensions in measuring TAE latent variable is moderate to high. The CVRed index shows that the inner TAE model has a high moderate quality. For the final conclusion on the quality of the model, the GOF index was used, the value of GOF indicates that our prediction quality is generally much higher than strong, and the TAE model has the power of prediction up to $97 \%$ of covariancebased SEM. Finally, the correlation coefficients between TAE, PANAS and TSES scales are significant, and criterion validity is confirmed. To compare the second and third order hierarchical models of Academic emotions in this study, information criteria EN, CAIC, BIC, and AIC were utilized. According to the BIC, CAIC and ENI second-order hierarchical TAE model has the lowest value, therefore, is a better model for teachers' academic emotions.

The results of this study are in line with the findings of Frenzel et al. (2016) and Hong et al. (2016), it confirms the three-factor structure of TES and the four-factor structure of AEQ-T. As noted in previous studies, the primary emotions, teachers experience in the educational environment were examined, but in addition to the primary emotions, the teacher may experience secondary emotions as well. The Secondary emotions appear after primary emotions and are emotional reactions to primaries or, in other words, they are feelings that we experience about primary ones. Since the response to one primary emotion may lead to several secondary ones, and the primary emotional reaction in one situation may develop an unending chain of secondary chaotic emotions (Mckay, Wood \& Brantley, 2007), it seems necessary to know the emotions in the educational environment, in order to cope with negative primary/secondary emotions and to reinforce the positive ones, and also take the effective ways of confrontation. Therefore, in this study, to measure TAE, the primary emotions (anxiety, enjoyment, anger, and pride) and secondary emotions (hope and despair, exhaustion, shame, and guilt) were analyzed and the structure of the nine-factor construct was approved and emphasized on the nature of the multidimensional structure of TAE.

The findings of researches by Zembylas (2005), Emmer (1994), Hargreaves (1998) and Sutton \& Wheatley (2003) regarding TAE suggest that teachers often experience a mix of positive (joy, passion, warmth, and affection) and negative emotions (anger, frustration, and anxiety. Accordingly, various categories of emotions are presented, Parrott (2001) developed a comprehensive list of emotions that are organized in a short structure, whereby the primary emotions are subdivided into secondary ones and secondary emotions into third-level emotions (Bahia, Freire, Amaral \& Teresa-Estrela, 2013). Chen (2016) examined teachers' emotions and developed a tool to measure it. These fundamental thrills related to the teacher's profession are happiness, love, sadness or grief, anger, and fear. Karshki, Koohi ve Ahani (2016) studied the dynamics of the Chen teacher's emotions scale at primary schools in Iran. The results of this study showed that Chen's five-factor teacher's emotions scale has a desirable inner consistency and sufficient validity in the sample of Iranian teachers. The results of this study are in line with the 
studies of other researchers, including Frenzel et al. (2016); Hong et al. (2016); Karshki, Koohi \& Ahani (2016); Hagenauer and Volt (2014); Cross and Hong (2012); Franzel; Guetz, Stephen \& Jacob (2009); Frenzel \& Guetz (2004); Lee \& Yen (2011) and others.

At the same time, despite the importance of emotions in the educational context, especially the desirable ones, studies and research in this area are limited by educators (Hosseini and Khayer, 2011). Guetz et al. (2003) emphasize that although educational emotions are inherently important due to their significance to well-being, the quality of learning, progress, and social interactions in the classroom, but there is little knowledge of this category of excitements and Their occurrences in field of education (Guetz, Zirringibl, Pekrun \& Hall, 2003). Karshki, Koohi, and Ahani (2016) emphasize that, despite the importance of teachers' emotion and its impact on various variables in Iran, it has not been addressed. The ability to recognize emotions is the most important step in controlling them. When we know what conditions are causing anger or anxiety, we try more than anything to avoid creating such situations for ourselves. This also applies to classrooms and teachers. The present study is a preliminary study on the psychometric properties of TAE Scale for secondary school teachers in Tehran. Therefore, considering the importance of emotions in the mental health of teachers as well as the role of teachers in the education process, in order to generalize the findings and create an effective recognition of the teachers' emotions in class, it is recommended that the TAE scale to be carried out at other levels and more widely, in the form of regional and national research.

Human as a complex being is the collection of thousands characteristics and modes. We as human, at any moment in our lives, are faced with different situations and conditions, and emotions and motives, and the whole set of our reactions to these situations that shape our lives. However, since the biological, psychoanalytic, cognitive development, psychoanalysis, social, sociological, cultural and anthropological views have defined emotions in various perspectives and categorized differently (primary or secondary, compound or simple, complex or pure, and positive or negative), it is suggested that considering the multidimensional nature and extent of the emotion spectrum, TAE model be examined in different categories and from different perspectives to present the model with the best fit.

Moreover, one of the wonders of creation is the existence of differences between men and women. These differences are diverse between cultures, civilizations, countries, and races because each of them has different standards of morality and equality between men and women. Biologists and researchers, after numerous studies, concluded that the emergence and conveying of emotions in women and men intrinsically, differentiated, and influenced by the gender they act in a different way from one another. Women tend to be more intense and more sensitive than men who are emerging and stimulating feelings and emotions. Studies show that men express their feelings less often, more secretive and less severe than women in the presence of others. Even many contemporary researchers and theorists argued that gender differences in expression of emotions tend to depend on the culture of social expectations and social behaviors (Reeve, 2015), rather than from the natural and biological differences between men and women. Since gender differences are effective in emotions due to natural, biological, cultural and social differences and etc., and given that currently, in researches in the field of academic emotions, The impact of gender groups has not been studied, it is suggested that, in addition to examining TAE scale, the gender-related measurement invariance should be considered, which, the subject has not been under investigation so far contrary to its importance. Besides, the measurement invariance matters because it is one of the conditions for scientific generalizability; but its proof requires strong shreds of evidence (Englehard, Hansche, \& Rutledge, 1990 as cited in Geramipour, 2014). Also, culture can be considered as a moderating variable in examining the multidimensional factors of TAE, in order to determine the role of culture in academic emotions and emotional regulation, and presenting an optimal model of TAE. Karshaki, Koohi, and Ahani (2011), in explaining their research findings, claim that the factor structure of the TAE questionnaires follows a similar pattern in different 
cultural contexts; therefore, despite the structural similarity, it is important to examine the intensity of the emotions experienced in cultural and sexual groups.

\section{Acknowledgement}

This work was supported by the Kharazmi University [grant numbers: 4/192574].

\section{References}

AminAbadi, Z., Dehghani, M., \& Khodapanahi, M. K. (2011). Investigating the factor structure and validity of the cognitive emotion regulation questionnaire. Journal of Behavioral Sciences, 5(4), 365-371.

Bahia, S., Freire, I., Amaral, A., \& Teresa Estrela, M. (2013). The emotional dimension of teaching in a group of Portuguese teachers. Teachers and Teaching, 19(3), 275-292.

Blair, C. (2002). School readiness: Integrating cognition and emotion in a neurobiological conceptualization of children's functioning at school entry. American Psychologist, 57, 111-127.

Brackett, M. A., Palomera, R., Mojsa-Kaja, J., Reyes, M., \& Salovey, P. (2010). Emotion-regulation ability, burnout, and job satisfaction among British secondary school teachers. Psychology in the Schools, 47 (4), 406-417. doi: $10.1002 /$ pits.20478

Burnham, K. P., \& D. R. Anderson, (2004). Multimodel Inference: understanding AIC and BIC in Model Selection, Amsterdam Workshop on Model Selection. Retrieved on October 2017 from http://student.uva.nl/en/content/az/wireless-internet/wirelessinternet.html?origin=KRqlSCJvTWW3Nl\%2FRMdykVg

Butler, R. (1994). Teacher communications and student interpretations: Effects of teacher responses to failing students on attributional inferences in two age groups. British Journal of Educational Psychology, 64, 277294

Chan, D. W. (2006). Emotional intelligence and components of burnout among Chinese secondary school teachers in Hong Kong. Teaching and Teacher Education, 22, 1042-1054. doi:10.1016/j.tate.2006.04.005

Chen, J. (2016). Understanding teacher emotions: The development of a teacher emotion inventory. Teaching and Teacher Education, 55, 68-77. doi:10.1016/j.tate.2016.01.001

Chin, W. W. (1998). The partial least squares approach to structural equation modelling. In G. A. Marcoulides (Ed.), Modern methods for business research (295-336). Mahwah, New Jersey: Lawrence Erlbaum Associates.

Conner, T. S., \& Barrett, L. F. (2012). Trends in ambulatory self-report: the role of momentary experience in $\begin{array}{llll}\text { psychosomatic } \quad \text { Psychosomatic } & \text { 74,327-337. }\end{array}$ http://dx.doi.org/10.1097/PSY.0b013e3182546f18

Cross, D. I., \& Hong, J. Y. (2012). An ecological examination of teachers' emotions in the school context. Teaching and Teacher Education, 28(7), 957-967. http://dx.doi.org/10.1016/j.tate.2012.05.001

Darby, A. (2008). Teachers' emotions in the reconstruction of professional self-understanding. Teaching and Teacher Education, 24, 1160-1172. doi:10.1016/j.tate.2007.02.001

Dennis, T. A., Hong, M., \& Solomon, B. (2010). Do the associations between exuberance and emotion regulation depend on effortful control? International Journal of Behavioural Development, 34, 462-472.

Denzin, N. K. (1984). On understanding emotion. San Francisco, CA: Jossey-Bass

Ekman, P. (1982). Emotion in the human face (2nd Ed.). Cambridge: Cambridge University Press.

Emmer, E. T. (1994). Toward an understanding of the primacy of classroom management and discipline. Teacher Education, 6, 65-69.

Fornell C, Larcker D. (1981). Evaluating structural equation models with unobservable and measuring error. Journal of High Technology Management Research, 2(10), 39-50.

Frenzel, A. C. (2014). Teacher emotions. In R. Pekrun \& L. LinnenbrinkGarcia (Eds.), International handbook of emotions in education (pp. 494-519). New York, NY: Routledge.

Frenzel, A. C., Goetz, T., Lüdtke, O., Pekrun, R., \& Sutton, R. (2009). Emotional transmission in the classroom: Exploring the relationship between teacher and student enjoyment. Journal of Educational Psychology, 101, 705-716. doi: 10.1037/a0014695

Frenzel, A. C., Goetz, T., Stephens, E. J., \& Jacob, B. (2009). Antecedents and effects of teachers' emotional experiences: An integrated perspective and empirical test. In P. A. Schutz \& M. Zembylas (Eds.), Advances in teacher emotion research: The impact on teachers' lives (pp. 129-152). New York, NY: Springer. doi: 10.1007/978-1-4419-0564-2_7 
Frenzel, A. C., Pekrun, R., \& Goetz, T. (2010). Achievement Emotions Questionnaire for Teachers (AEQ-teacher) User's manual. University of Munich: Department of Psychology

Frenzel, A.C., Pekrun, R., Goetz, T., Daniels, L. M., Durksen, T. R., Becker-Kurz, B., \& Klassen, R. M. (2016) Measuring Teachers' enjoyment, anger, and anxiety: The Teacher Emotions Scales (TES). Contemporary Educational Psychology, 46, 148-163.

Gefen D, Straub DW. (2005). A practical guide to factorial validity using PLS-Graph: Tutorial and annotated example. Communi AIS, 16(5), 91-109.

GeramiPour, M. (2014). Evaluation of statistical power of logistic regression analysis in detecting the through Differential Item Functioning (DIF) of test questions. Quarterly Journal of Measuring and Educational Evaluation Studies, 4(8), 187-211.

Gläser-Zikuda, M., Stuchlíková, I \& Janík, T. (2013) Emotional Aspects of Learning and Teaching: Reviewing the Field -Discussing the Issues. ORBIS SCHOLAE, 7(2), 7-22.

Goetz T., Zirngibl A., Pekrun R., Hail, N.C. (2003). Emotion, learning, and achievement form an educational psychological perspective. In P. Mayrning \& C. Rhoeneck (Eds), learning emotion: the influence of affective factors on classroom learning (p.190). Frankfurt am Main: Peter Leng.

Goetz, T., Becker, E. S., Bieg, M., Keller, M. M., Frenzel, A. C., \& Hall, N. C. (2015). The glass half empty: How emotional exhaustion affects the state-trait discrepancy in self-reports of teaching emotions. PLoS ONE, 10(9), e0137441.Retrieved on October 2017 from: http:/ / dx.doi. org/10.1371/journal.pone.0137441

Gross, J. J., Thompson, R. A. (2007). Emotion regulation: Conceptual foundations. In JJ. Gross (Ed.), Handbook of emotion regulation (pp. 3-24). New York: Guilford Press.

Hagenauer, G., \& Volet, S. E. (2014). "I don't hide my feelings, even though I try to": insight into teacher educator emotion display. The Australian Educational Researcher, 41(3), 261-281. http://dx.doi.org/10.1007/s13384-013-0129-5.

Hair J. F. (2006). Multivariate data analysis. Upper Saddle River, NJ: Pearson Prentice Hall.

Hair, J. F., Black, W. C., Babin, H. J., \& Anderson, R. E. (2010). Multivariate Data Analysis (7th ed.). New Jersey: Prentice Hall.

Hair, J. F., Sarstedt, M., Pieper, T. M, Ringle, C. M. (2012). The use of partial least squares structural equation modelling in strategic management research: A review of past practices and recommendations for future applications. Long Range Planning, 45(5-6), 320-340.

Hair, J. F., Sarstedt, M., Ringle, C. M., \& Gudergan, S. P. (2017). Advanced Issues in Partial Least Squares Structural Equation Modelling (PLS-SEM). Thousand Oaks, CA: Sage.

Hair, J. F., Ringle, C. M., \& Sarstedt, M. (2013). Partial Least Squares Structural Equation Modelling: Rigorous Applications, Better Results, and Higher Acceptance. Long Range Planning, 46(1-2), 1-12.

Hargreaves, A. (1998). The emotional practice of teaching. Teaching and Teacher Education, 14, 835-854.

Hargreaves, A. (2005). Educational change takes ages: Life, career and generational factors in teachers 'emotional responses to educational change. Teaching and Teacher Education, 21(8), 967-983. doi: 10.1016/j.tate.2005.06.007

Henseler, J., Ringleand, C. M., \& Sinkovics, R. R. (2009). The Use of Partial Least Squares Path Modelling in International Marketing. New Challenges to International Marketing Advances in International Marketing, 20, $277-319$

Hong, J., Nie, Y., Heddy, B., Monobe, G., Ruan, J., You, S., \& Kambara, H. (2016). Revising and Validating Achievement Emotions Questionnaire - Teachers (AEQ-T). International Journal of Educational Psychology, 5(1), 80-107.

Hosseini, F. S. \& Khayer, M. (2011). The role of cognitive assessment in explaining the relationship between parenting dimensions with mathematics educational emotions and emotion regulation. Educational and Learning Studies, 3(1), 17-46.

Hulland, J. (1999). Use of partial least squares (PLS) in strategic management research: a review of four recent studies. Strategic Management Journal, 20(2), 195-204.

Kleine, M., Goetz, T., Pekrun, P. \& Hall, N. (2005). The structure of students' emotions experienced during a mathematical achievement test. International Reviews on Mathematical Education, 37, 221-225.

Kline, R. B. (2010). Principles and Practice of Structural Equation Modelling. New York: Guilford Press.

Lazarus, R. S. (1991). Emotion and adaptation. New York, NY: Oxford University Press.

Lazarus, R. S. (1994). The stable and the unstable in emotion. In P. Ekman \& R. J. Davidson (Eds.), The Nature of Emotion. Fundamental Questions (pp. 79-85). Oxford: Oxford University Press.

Lazarus, R. S. (1999). Stress and emotions: A new synthesis. New York, NY: Springer. 
Lee, J. C. K., \& Yin, H. B. (2011). Teachers' emotions and professional identity in curriculum reform: A Chinese perspective. Journal of Education Change, 12(1), 25-46.

Lee, M., Pekrun, R., Taxer, J. L., Schutz, P. A., Vogl, E., \& Xie, X. (2016). Teachers' emotions and emotion management: integrating emotion regulation theory with emotional labor research. Social Psychology of Education. Retrieved on October 2017 from http://link.springer.com/article/10.1007\%2Fs11218-016-93595

Marsella, A. J, \& Leong, F. T. L. (1995). Cross-cultural issues in personality and career assessment, Journal of Career Assessment, 3, 202-218.

McKay, M., Wood, J., \& Branetley, J. (2007). The Dialectical Behaviour Therapy Skills Workbook: Practical DBT Exercises for Learning Mindfulness, Interpersonal Effectiveness, Emotion Regulation, and Distress Tolerance. Oakland, USA: New Harbinger Publications.

Moors, A., Ellsworth, P. C., Scherer, K. R., \& Frijda, N. H. (2013). Appraisal theories of emotion: state of the art and future development. Emotion Review, 5(2), 119-124.

Newberry, M., Gallant, A. \& Riley, P. (2013). Emotion and School: Understanding how the Hidden Curriculum Influences relationships, leadership, teaching, and learning. UK: Emerald.

O'Connor, K. E. (2008). "You choose to care": Teachers, emotions, and professional identity. Teaching and Teacher Education, 24(1), 117-126.

Parrott, W. (2001). Emotions in social psychology. Philadelphia: Psychology Press. Retrieved on September 2016 from http://www.amazon.com

Pekrun, R. (1992). The impact of emotions and learning and achievement: Towards a theory of cognitive/motivational mediators. Applied Psychology: An International Review, 41(4), 359-376.

Pekrun, R. (2006). The control-value theory of achievement emotions: Assumptions, corollaries, and implications for educational research and practice. Educational Psychology Review, 18, 315-341.

Pekrun, R., Goetz, T., Frenzel, A. C., \& Perry, R. P. (2011). Measuring emotions in students' learning and performance: The achievement emotions questionnaire (AEQ). Contemporary Educational Psychology, 36, 36-48. Retrieved on August 2016 from http:/ / dx.doi.org/10.1016/j.cedpsych.2010.10.002.

Pekrun, R., Goetz, T., Perry, R. P., Kramer, K., Hochstadt, M., \& Molfenter, S. (2004). Beyond test anxiety: Development and validation of the test emotions questionnaire (TEQ). Anxiety, Stress, and Coping: An International Journal, 17, 287-316.

Pekrun, R., Götz, T., Titz, W., \& Perry, R. P. (2002). Academic emotions in students' self-regulated learning and achievement: A program of qualitative and quantitative research. Educational Psychologist, 37(2), 91-105.

Raouf, A. (2004). Teachers Actors for Science Promotion. Rahyaft, 32, Retrieved on March 2016 from http:/ / login.nrisp.ac.ir:800/Repository / ArticleFile/a6bc35c3-7973-4de6-a2c7-fdcfe4f189ed.pdf

Reeve, J. (2015). Understanding Motivation and Emotion (6th Ed.). Hoboken, NJ: Wiley.

Roseman, I. J. (2001). A model of appraisal in the emotion system: Integrating theory, research, and applications. In K. R. Scherer, A. Schorr \& T. Johnstone (Eds.), Appraisal processes in emotion (pp. 68-91). Oxford, UK: Oxford University Press.

Sallquist, J. V., Eisenberg, N., Spinrad, T. L., Reiser, M., Hofer, C., Zhou, Q., \& Eggum, N. (2009). Positive and negative emotionality: Trajectories across six years and relations with social Competence. Emotion, 9, $15-28$.

Scherer, K. R. (1984). On the nature and function of emotion: A component process approach. In P. Ekman (Ed.), Approaches to emotion. Hillsdale: Erlbaum.

Scherer, K. R. (2009). The dynamic architecture of emotion: Evidence for the component process model. Cognition and Emotion, 23, 1307-1351. http://dx.doi.org/10.1080/02699930902928969.

Scherer, K. R. (2013). Measuring the meaning of emotion words: A domain-specific componential approach. In J. Fontaine, K. Scherer, \& C. Soriano (Eds.), Components of emotional meaning. A sourcebook (pp. 46-62). Oxford: Oxford University Press.

Scherer, K. R., Schorr, A., \& Johnstone, T. (Eds.). (2001). Appraisal processes in emotion. Oxford, UK: Oxford University Press.

Schutz, P. A., \& Lanehart, S. L. (2002). Introduction: Emotions in education. Educational Psychologist, 37(2), 67-68.

Schutz, P. A., Cross, D. I., Hong, J. Y., \& Osbon, J. N. (2007). Teacher identities, beliefs, and goals related to emotions. In Schutz, P.A., Pekrun, R., (Eds.), Emotion in Education (pp. 223-242). London, UK: Elsevier.

Schutz, P.A. \& Zembylas, M. (2009). Advances in Teacher Emotion Research: The Impact on Teachers' Lives. New York: Springer. 
Shoarinejad, A. (2015). Psychology of Education and Teaching. Tehran: Etelaat.

Smith, C. A., \& Lazarus, R. S. (1993). Appraisal components, core relational themes, and the emotions. Cognition and Emotion, 7(3/4), 233-269.

Sutton, R. E. (2007). Teachers' anger, frustration, and self-regulation. In P. A. Schutz \& R. Pekrun (Eds.), Emotion in education (pp. 251-266). San Diego: Academic Press.

Sutton, R. E., \& Harper, E. (2009). Teachers' emotion regulation. In L. J. Saha, \& A. G. Dworkin (Eds.), International handbook of research on teachers and teaching (pp. 389-401). New York: Springer.

Sutton, R. E., \& Wheatley, K. F. (2003). Teachers' emotions and teaching: A review of the literature and directions for future research. Educational Psychology Review, 15(4), 327-358. doi: 10.1023/ A:1026131715856

Taxer, J. L., \& Frenzel, A. C. (2015). Facets of teachers' emotional lives: A quantitative investigation of teachers' genuine, faked, and hidden emotions. Teaching and Teacher Education, 42, 78-88. doi:dx.doi.org/10.1016/ j.tate.2015.03.003

Tenenhaus, M., Amato, S., \& Vinzi, E. V. (2004). A global goodness-of-fit index for PLS structural equation modelling. In Proceeding of the XLII SIS scientific meeting, (pp. 739-742).

Tenenhaus, M., Vinzi, V. E., Chatelin, Y.-M., \& Lauro, C. (2005). PLS path modelling. Computational Statistics $\mathcal{E}$ Data Analysis, 48(1), 159-205.

Vinzi, E., Trinchera, L., \& Amato, S. (2010). PLS path modelling: from foundations to recent developments and open issues for model assessment and improvement. In Vinzi, E., Chin, W.W., Henseler, J., Wang, H. (Eds.), Handbook of Partial Least Squares: Concepts, Methods and Applications in Marketing and Related Fields (pp.47-82). Berlin: Springer.

Watson, D., Wiese, D., Vaidya, J., \& Tellegen, A. (1999). The two general activation systems of affect: Structural findings, evolutionary considerations, and psychobiological evidence. Journal of Personality and Social Psychology, 76, 820-838.

Wirtz, D., Kruger, J., Scollon, C. N., \& Diener, E. (2003). What to do on spring break? The role of predicted, on-line, and remembered experience in future choice. Psychological Science, 14(5), 520-524. Retrieved on August 2016 from http:/ / dx.doi.org/10.1111/1467-9280.03455

Yin, H. (2016). Knife-like mouth and tofu-like heart: emotion regulation by Chinese teachers in classroom teaching. Social Psychology of Education, 19(1), 1-22.

Yin, H., Huang, S. \& Wang, W. (2016). Work Environment Characteristics and Teacher Well-Being: The Mediation of Emotion Regulation Strategies. International Journal of Environmental Research and Public Health, 13(9), 907.

Zembylas, M. (2005). Beyond teacher cognition and teacher beliefs: The value of the ethnography of emotions in teaching. International Journal of Qualitative Studies in Education, 18(4), 465-487. 